\title{
ENZYMATIC DEGRADATION OF AZO DYES USING PEROXIDASE IMMOBILIZED ONTO COMMERCIAL CARRIERS WITH EPOXY GROUPS
}

\author{
PAULA BORZA ${ }^{a}$, IOANA CRISTINA BENEA ${ }^{a}$, IOAN BÎTCAN ${ }^{a}$, \\ ANAMARIA TODEA ${ }^{\mathrm{a}^{*}}$, SIMONA GABRIELA MUNTEAN ${ }^{\mathrm{b}^{*}}$, \\ FRANCISC PETER ${ }^{a}$
}

\begin{abstract}
The treatment of colored wastewater has been paid attention in the recent years because of the high amount of dyes, mostly carcinogenic, discharged into the water. Enzymatic degradation shows several advantages such as: shorter processing time, reduction in sludge volume and ease of controlling the process. In this work, seven different industrial dyes were tested as substrates for horseradish peroxidase. The native enzyme was covalently immobilized onto two types of epoxy-supports, different in spacer length. Among the tested dyes the highest substrate conversions were achieved for Amido Black 10 (AB10). The highest recovered activity was obtained when the epoxy-activated support with longer spacer arm was used. After ten reuse cycles for the degradation of AB10, the covalently bound peroxidase preserved about $80 \%$ of the initial activity.
\end{abstract}

Keywords: horseradish peroxidase, biocatalysis, ReliZyme ${ }^{\mathrm{TM}}$ support, covalent immobilization, dye degradation, environment

\section{INTRODUCTION}

The use of enzymes for treatment of waste waters containing dyes was intensively studied, based on the capacity of enzymes to modify the original structure of dyes and thus obtaining compounds that can be degraded or eliminated more easily [1,2,3]. A wide range of enzymes, mainly oxidoreductases, have been proven to be excellent catalysts in the wastewater purification process, due to the mild reaction conditions, the ability to transform complex substances and higher reaction rates compared to chemical catalysts $[2,3,4]$. Oxidoreductases are able to catalyze degradation of phenols, anilines, benzidines, chlorophenols and various heterocyclic aromatic substances [5].

\footnotetext{
a University Politehnica Timisoara, Faculty of Industrial Chemistry and Environmental Engineering, Biocatalysis Group, C. Telbisz 6, 300001 Timisoara, Romania

b "Coriolan Drăgulescu" Institute of Chemistry, Mihai Viteazul 24, 300223 Timisoara, Romania

* Corresponding authors: anamaria.todea@upt.ro, sgmuntean@acad-icht.tm.edu.ro
} 
Several factors can influence the degradation of residual dyes, such as the concentration and structure of dye, the presence of other compounds, $\mathrm{pH}$ and temperature of the effluent [6]. When enzymes are employed for the elimination of pollutants from waste waters, the properties of the biocatalyst must be properly tuned in order to ensure the highest efficiency, considering all these factors. Plant peroxidases have been extensively studied as a useful tool for bioremediation of industrial waste. Particularly, horseradish peroxidase (HRP) is a widely used catalyst in enzymatic reactions [7]. HRP proved important advantages including high activity and selectivity, high resistance to inhibition by various compounds over a broad concentration range, as well as high operability and reliability in different treatment conditions [5]. Studies have shown that in the presence of $\mathrm{H} 2 \mathrm{O} 2 \mathrm{HRP}$ can effectively precipitate a wide variety of organic compounds, aromatic compounds, and recalcitrant contaminants, such as dyes and phenolic compounds. HRP has been extensively used in wastewater treatments as it offers long lifetime, stability and also retention of the enzymatic activity over a broad range of temperature and $\mathrm{pH}$ [8].

Recently it was found that chlorophenols, labeled as "priority pollutants" by the US Environmental Protection Agency, can be removed from contaminated water by HRP. Like other native enzymes, HRP has several drawbacks such as low stability, short lifetime, high susceptibility to inactivation, and difficulty in re-using [9]. Immobilization proved to be a viable solution to overcome these drawbacks, improving the activity, stability, and recovery of the enzyme. Moreover, immobilized enzymes could be broadly applied to various reaction environments and harsh conditions [9].

The immobilization of HRP was carried out using several supports: modified chitosan, polymeric acrylamide matrix, alginate, glycidyl methacrylate copolymers, glutaraldehyde-activated aminopropyl glass beads, magnetite, ion exchange resins, and various polymers $[4,11,12,13]$.

Immobilization by covalent binding is considered appropriate for obtaining solid-phase biocatalysts with high operational stability [14]. Alongside the physical properties of the support, the structure and reactivity of the active group attached to the carrier is essential for a successful immobilization. Epoxy activated supports are very stable, can be stored for a long time and can be applied for immobilization of the enzymes to be used in the laboratory or at industrial scale [15]. Immobilization of enzymes on supports activated with epoxy groups is achieved by covalent bonding, thus increasing the stability of the enzyme, and diminishing the possible adverse effects of organic solvents, formed 9 products or temperature on the activity of the enzyme $[16,17]$. Covalent bonds are formed between the support and nucleophilic groups from the enzyme structure, such as amino, hydroxy or thiol groups. By covalent immobilization on such supports, the conformational changes are greatly diminished [16]. 
There are reports of immobilization on epoxy-activated polyacrylamide beads, like as Eupergi $C$ [18]. Another possibility is to use a long-chained cross-linker holding epoxy groups. A $\mathrm{ZnO}$ nanowires/macroporous $\mathrm{SiO}_{2}$ nanocomposite was used as support for HRP immobilization by in situ crosslinking, with diethylene glycol diglycidyl ether as cross-linker [19].

Although there are several studies on HRP immobilization, the utilization of commercial epoxy-functionalized methacrylate carriers was not yet reported. Compared to many other support materials, these carriers have the advantage of reproducible properties, large-scale availability, and convenient price. The aim of the present study was to develop a protocol for the covalent immobilization of HRP on epoxy-functionalized beads and to use the obtained biocatalysts for the degradation of industrial azo dyes. The effects of temperature and $\mathrm{pH}$ on the enzyme activity, as well as the operational stability have been evaluated for both free and immobilized

$\mathrm{HRP}$, using $A B 10$ dye as model substrate. The influence of hydrogen peroxide concentration was also studied. The results may provide new opportunities for the application of immobilized enzymes in the field of environmental protection, allowing the efficient oxidative degradation of residual dyes.

\section{RESULTS AND DISCUSSION}

\section{The selectivity of HRP for commercial azo dyes}

The selectivity of the HRP was tested using the native enzyme and six substrates, at $25^{\circ} \mathrm{C}$ and two $\mathrm{pH}$ values, 3.5 and 6.0 . The chemical structures of the selected dyes are presented in Figure 1S (Supplementary material). The results obtained after $24 \mathrm{~h}$ of reaction, shown in Figure 1, indicate that at $\mathrm{pH} 3.5$ the conversions were lower compared to those obtained at $\mathrm{pH} 6.0$, except for the Neutral gray dye. At pH 6, the highest conversions values (up to $80 \%$ ) were obtained for Amido Black 10 (AB 10) and Acid Orange 7 (AO 7) dyes.

Considering these results, the $A B 10$ dye was used as substrate in the following experiments.

\section{The effect of hydrogen peroxide concentration}

Recent studies have shown that for HRP there is an optimal hydrogen peroxide/dye molar ratio [2]. However, addition of excess hydrogen peroxide, after conversion has reached optimal value, favored the dye degradation process. A possible explanation for this phenomenon might be that addition of excess $\mathrm{H}_{2} \mathrm{O}_{2}$ at the beginning of the process leads to formation of a larger amount of intermediate products which inhibit the peroxidase activity, or even excess hydrogen peroxide can inhibit the activity of the enzyme [2]. 
PAULA BORZA, IOANA CRISTINA BENEA, IOAN BITTCAN, ANAMARIA TODEA, SIMONA GABRIELA MUNTEAN, FRANCISC PETER

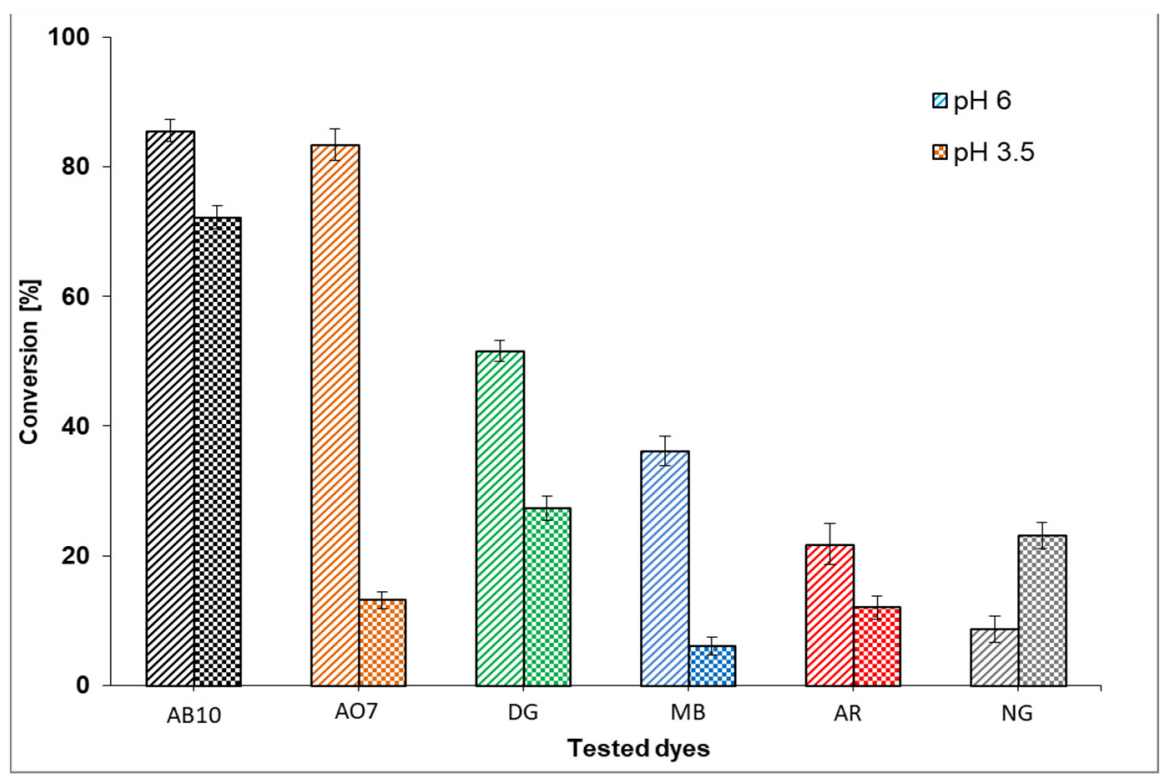

Figure 1. Comparative evaluation of the selectivity of HRP for degradation of six different dyes (AB 10 - Amido Black 10, AO7 - Acid Orange 7, DG - Direct green; MB - Methylene blue; AR - Acid red; NG - Neutral grey)

As hydrogen peroxide acts as co-substrate, three concentrations were tested. The results, presented in Figure 2, show that at concentrations higher than $1.43 \mathrm{mM}$ there were no changes in activity, therefore in the subsequent studies the $\mathrm{H}_{2} \mathrm{O}_{2}$ concentration was set at $1.43 \mathrm{mM}$.

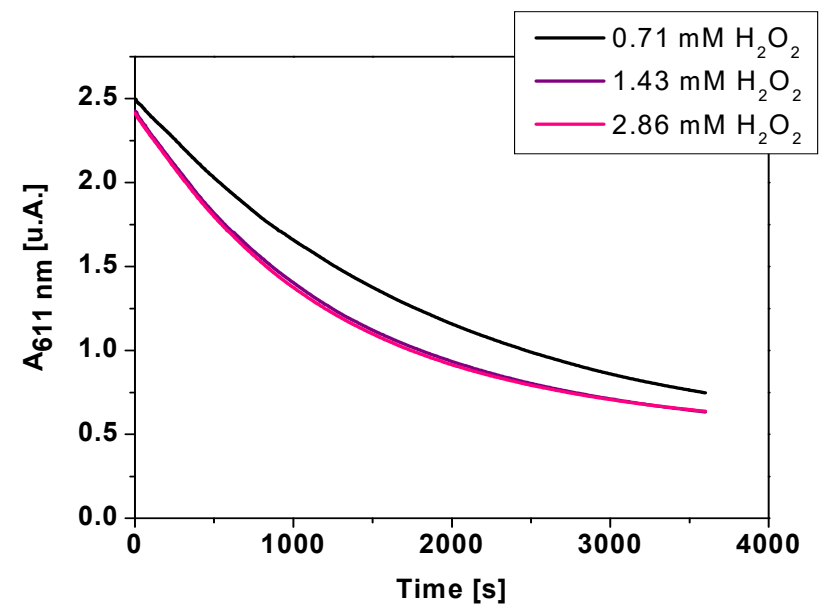

Figure 2. The effect of hydrogen peroxide amount on the decrease of absorbance at $611 \mathrm{~nm}$ in time, using AB10 dye as substrate 


\section{Immobilization of HRP onto ReliZyme ${ }^{\mathrm{TM}}$ supports}

The practical interest on peroxidases, illustrated by the increasing number of publications in the past years, reveals that the research towards stabilization of this enzyme still presents scientific importance. Among the available immobilization methods, a simple and rapid covalent binding was selected. Considering that the biocatalyst was designed to be used in aqueous solutions, the covalent binding could also avoid the leaching of the enzyme from the support.

Two commercial ReliZyme ${ }^{\mathrm{TM}}$ supports, with active epoxy groups and different chain length and structure of the spacer arm, were selected (Table 1). The immobilization was performed in a single step, by mixing the enzyme solution with the support for $24 \mathrm{~h}$. The activity of the immobilized HRP was determined by using ABTS as substrate, as described in the experimental part. The results, presented in Table 1, indicate high protein loading values $(>90 \%)$, for both support types. The specific activity and the reproducibility were higher when the epoxy-amino HFA 403 support was used. Probably, the longer spacer arm favors multipoint covalent attachment of the enzyme to the epoxy groups of the support. However, considering the high immobilization efficiencies, the characterization studies were performed for both biocatalysts and the results were compared to the native enzyme.

Table 1. Protein loading and recovered activity of HRP immobilized onto epoxy- Relizyme ${ }^{\mathrm{TM}}$ supports

\begin{tabular}{|l|c|c|}
\hline Type of the solid support & $\begin{array}{c}\text { Protein loading } \\
{[\%]}\end{array}$ & $\begin{array}{c}\text { Specific activity } \\
{\left[\mathrm{U} \mathrm{g} \mathrm{protein}-{ }^{-1}\right]}\end{array}$ \\
\hline HFA 403 & 93.5 & $21.24 \pm 2.36$ \\
\hline
\end{tabular}

Comparative characterization of the native and immobilized horseradish peroxidase

\section{Modification of the $\mathrm{pH}$ profile by immobilization}

$\mathrm{pH}$ is one of the most important factors influencing the enzyme activity, because at extreme $\mathrm{pH}$ values the activity can be inhibited [20]. Often, for native enzymes the highest activity is in a relatively narrow $\mathrm{pH}$ range, and this shortcoming can be overcome by immobilizing the enzyme [20,21]. The reactions 
were carried out at $25^{\circ} \mathrm{C}$, in the presence of $1.43 \mathrm{mM} \mathrm{H}_{2} \mathrm{O}_{2}$, for 30 minutes, under stirring at $300 \mathrm{rpm}$. Compared to the native enzyme that showed the optimal $\mathrm{pH}$ at 5 , the activity of the immobilized biocatalyst was improved over the whole tested $\mathrm{pH}$ range (Figure 3 ).

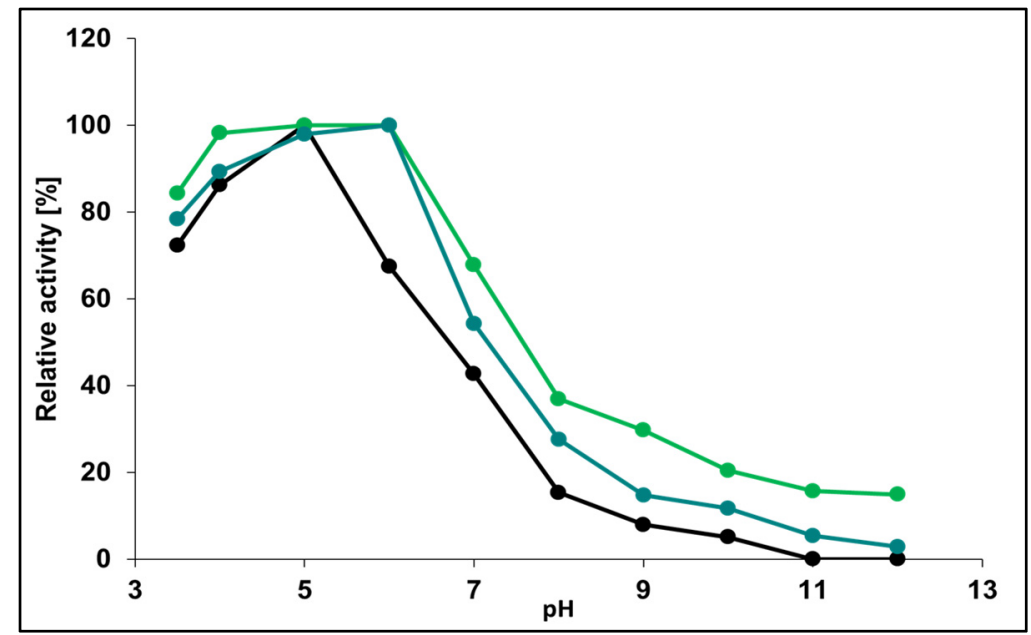

Figure 3. Effect of $\mathrm{pH}$ on the decolorization of Amido Black 10 dye by native (black color), and immobilized HRP on HFA 403 (green color) and EP 403 (turquoise color) carriers. Reaction conditions: $25^{\circ} \mathrm{C}, 30 \mathrm{~min}, 1.43 \mathrm{mM} \mathrm{H}_{2} \mathrm{O}_{2}, 300 \mathrm{rpm}$

The highest activity was obtained for the HRP-HFA biocatalyst, in the $\mathrm{pH}$ range 4-7.

An improvement of the $\mathrm{pH}$ stability of HRP by immobilization was also observed by Bilal et al., when calcium alginate was used as support and glutaraldehyde as linker [23]. The activity of the immobilized HRP on calcium alginate was at least $10 \%$ higher in the range $7-9$ compared to the native enzyme. Mohameda et al. immobilized HRP onto activated wool support and Wool-HRP showed broad optimum pH at 7.0-8.0 [24].

\section{Effect of temperature on the stability of immobilized peroxidase}

The stability of the enzymes decreases with increasing temperature, he enzyme becoming inactive at high temperatures, due to the irreversible modification of the tertiary structure. Several studies concluded that thermal inactivation can be limited by enzyme immobilization [20]. To evaluate the effect of temperature on the enzymatic activity, the native and immobilized enzymes were incubated for $1 \mathrm{~h}$ at $25^{\circ} \mathrm{C}, 35^{\circ} \mathrm{C}, 45^{\circ} \mathrm{C}$ and $55^{\circ} \mathrm{C}$, in buffer solution pH 5.0, then cooled at $25^{\circ} \mathrm{C}$ when the model substrate (AB10) was added. The assay was carried out in the presence of $1.43 \mathrm{mM} \mathrm{H}_{2} \mathrm{O}_{2}$, for 30 minutes at $300 \mathrm{rpm}$. 


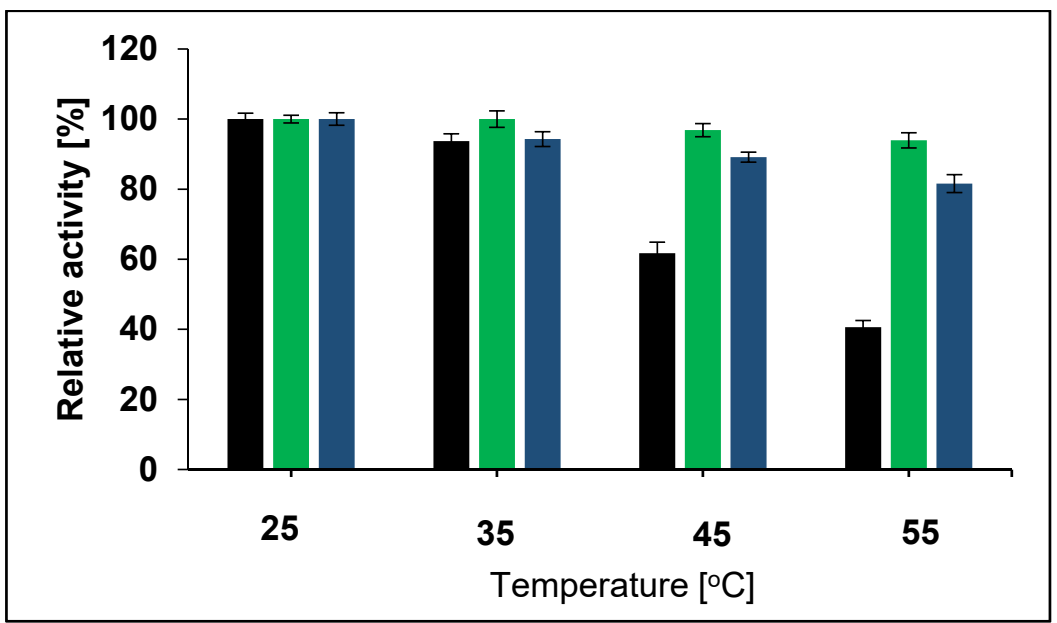

Figure 4. Thermal stability of native (black color) and immobilized horseradish peroxidase (on HFA 403, green color; on EP 403, turquoise color). The degradation of Amido Black 10 dye was carried out at $25^{\circ} \mathrm{C}, 30 \mathrm{~min}, 300 \mathrm{rpm}$, in presence of $1.43 \mathrm{mM} \mathrm{H}_{2} \mathrm{O}_{2}$

The results (Figure 4 ) indicate up to $60 \%$ activity loss for the native HRP with increasing temperature in the studied range, while the enzyme immobilized on both HFA 403 and EP 403 demonstrated excellent thermostability (only $6.1 \%$ and $18.4 \%$ decrease, respectively). Among the two preparations, the HRP immobilized on HFA 403 showed superior thermal stability. Compared to $\sim 84 \%$ recovered activity value for decoloring of Acid Black dye after incubation at $55^{\circ} \mathrm{C}$, reported by Sun et al. for HRP immobilized onto $\mathrm{ZnO}$ nanowires/ macroporous $\mathrm{SiO}_{2}$ and diethylene glycol diglycidyl ether as cross-linker [19], the $93.8 \%$ value obtained in this study indicates a higher thermal stability after immobilization, which could be explained by the multipoint attachment of the cross-linked HRP, improving the rigidification of the protein and protect it from denaturation [19].

\section{Operational stability of the immobilized enzyme}

To increase the operational stability of the enzymes, in order to be reused in several production cycles, is one of the main objectives of immobilization. Provided that the immobilized enzyme does not lose its activity even after prolonged operational period, it can be employed in both continuous and discontinuous processes and the costs become lower [22].

The degradation of Amido Black 10 by HRP immobilized on HFA-403 epoxy-activated beads was studied in repeated batch reaction cycles, considering the activity of the first batch as reference. After ten cicles the relative activity 
remained about $80 \%$ (Figure 5), an excellent value for an enzyme working in aqueous environment. Compared to previous literature reports concerning the reuse of HRP immobilized by different methods (Table 2), the operational stability of our preparate was higher, indicating the efficiency of the selected immobilization support and method.

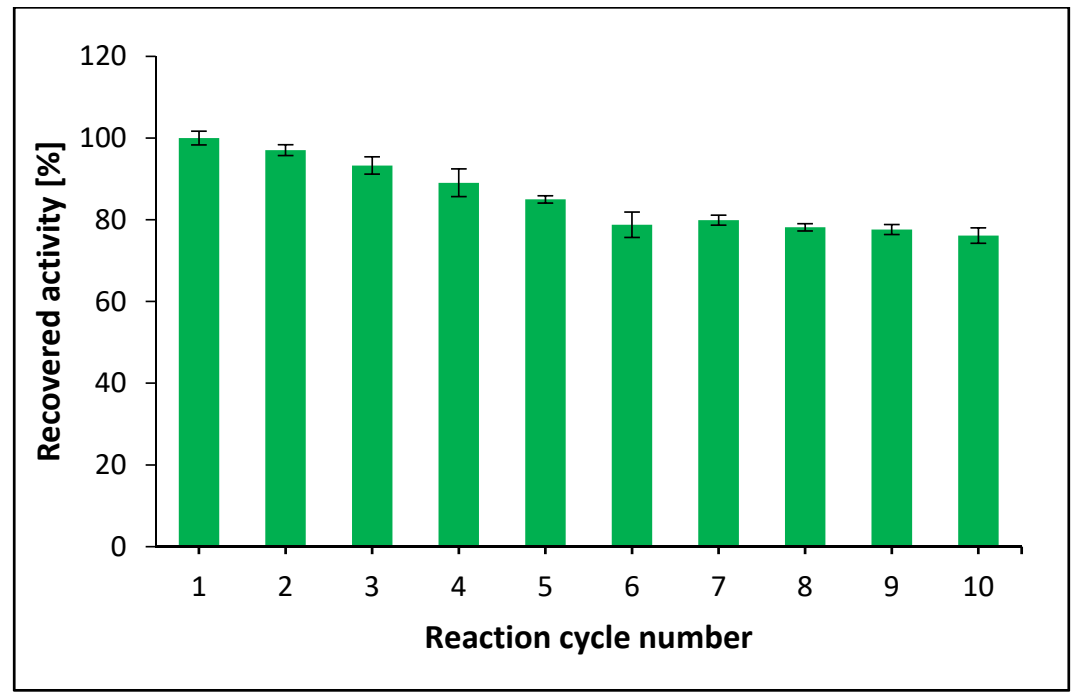

Figure 5. Stability of the peroxidase immobilized on HFA 403 epoxy beads, in repeated batches of Amido Black 10 degradation at $35^{\circ} \mathrm{C}, 30 \mathrm{~min}, 1.43 \mathrm{mM} \mathrm{H}_{2} \mathrm{O}_{2}, 300 \mathrm{rpm}$.

Table 2. Comparative evaluation of several immobilized horseradish peroxidases, based on the recovered activities after repeated reaction cycles

\begin{tabular}{|l|l|l|l|l|l|}
\hline $\begin{array}{l}\text { Immobilization } \\
\text { method }\end{array}$ & Support & Linker & $\begin{array}{l}\text { Reaction } \\
\text { cycles }\end{array}$ & $\begin{array}{l}\text { Recovered } \\
\text { activity [\%] }\end{array}$ & Ref. \\
\hline Encapsulation & chitosan beads & - & 6 & 64.9 & {$[25]$} \\
\hline Covalent binding & calcium-alginate & GA $^{*}$ & 7 & 40.0 & {$[23]$} \\
\hline Covalent binding & activated wool & hydrazine & 7 & 50.0 & {$[24]$} \\
\hline Covalent binding & chitosan beads & $\begin{array}{l}\text { hydrate } \\
\text { hydrate }\end{array}$ & 6 & 65.8 & {$[25]$} \\
\hline Covalent binding & $\begin{array}{l}\text { cashew gum } \\
\text { polysacch. }\end{array}$ & GA & 9 & 50.0 & {$[27]$} \\
\hline Covalent binding & nano-composite & $\begin{array}{l}\text { epoxy cross- } \\
\text { linker }\end{array}$ & 12 & 71.1 & {$[19]$} \\
\hline Covalent binding & $\begin{array}{l}\text { ReliZyme } \\
\text { HFA 403 }\end{array}$ & - & 10 & 76.1 & $\begin{array}{l}\text { This } \\
\text { study }\end{array}$ \\
\hline
\end{tabular}

*glutaraldehyde 


\section{CONCLUSIONS}

Horseradish peroxidase was successfully immobilized by covalent bonding, on two Relizyme ${ }^{\mathrm{TM}}$ supports containing active epoxy groups. The immobilization on the HFA 403 support proved to be more advantageous, allowing probably a multipoint linkage. By immobilization, both the stability and the activity of the enzyme were improved over a wider range of $\mathrm{pH}$, particularly in the $\mathrm{pH}$ range 5-6, which represents the typical $\mathrm{pH}$ of waters contaminated with dyes. In the basic domain, the enzymatic activity decreased significantly, but even at $\mathrm{pH} 11$ the immobilized enzyme was still active, unlike the native enzyme which was completely inactivated.

The thermostability of the enzyme was considerably enhanced by immobilization. In the case of peroxidase immobilized on HFA $403,90 \%$ of the initial enzymatic activity was recovered after incubation for 30 minutes at $55^{\circ} \mathrm{C}$, while the native enzyme lost $\sim 60 \%$ activity in the same conditions.

The selected immobilization method and support were also able to provide a stable end robust enzyme, suitable for several utilization cycles at high residual activity. The immobilized enzyme was successfully reused in batch decolorization processes, the activity remaining at $80 \%$ of the initial value after 10 cycles of use.

\section{EXPERIMENTAL SECTION}

\section{Chemicals}

Amido Black $10 \mathrm{~B}$ (AB10), Acid Orange (AO7), Acid Red (AR), Direct Green (DG), Methylene Blue (MB), Neutral Gray (NG) dyes were purchased from Merck (Germany) and Loba-Feinchemie (Austria). Sodium hydrogen phosphate, sodium dihydrogen phosphate (used to prepare the buffer solutions), hydrogen peroxide $35 \%$, citric acid, boric acid, trisodium phosphate, and 2,2'azino-di (3-ethylbenzothiazoline-6-sulfonate) (ABTS) were from Sigma-Aldrich Chemie $\mathrm{GmbH}$ (Germany). The horseradish peroxidase (HRP) used in the immobilization process and as reference native enzyme was also purchased from Merck. Both commercial supports utilized for covalent immobilization of HRP were products of Resindion S.r.I (Italy), a subsidiary of Mitsubishi Chemical: ReliZyme ${ }^{\mathrm{TM}}$ HFA 403 and ReliZyme ${ }^{\mathrm{TM}}$ EP 403 (polymethacrylate beads with oxiranyl active groups which differ by the length and structure of the spacer, oxirane content $\mathrm{min}$. $30 \mu \mathrm{mol} / \mathrm{g}$ wet, average pore diameter $40 \div 60 \mathrm{~nm}$ ). 
PAULA BORZA, IOANA CRISTINA BENEA, IOAN BÎTCAN, ANAMARIA TODEA, SIMONA GABRIELA MUNTEAN, FRANCISC PETER

\section{Determination of peroxidase activity using ABTS}

The activity of the immobilized HRP was tested using a known method with ABTS as substrate [28]. $20 \mu \mathrm{L}$ native peroxidase solution of $(1 \mathrm{mg} / \mathrm{mL})$, or $10 \mathrm{mg}$ immobilized peroxidase, were added to $100 \mu \mathrm{L}$ of $3 \mathrm{mM}$ ABTS, followed by addition of $1498 \mu \mathrm{L}$ citrate-phosphate buffer solution $\mathrm{pH} 5$ and $40 \mu \mathrm{L} \mathrm{H}_{2} \mathrm{O}_{2}$. The absorbance was measured at $414 \mathrm{~nm}$, after 5 minutes incubation at $25^{\circ} \mathrm{C}$, using a Jasco V-530 UV/vis Spectrophotometer (JASCO, Japan).

\section{Effect of hydrogen peroxide concentration}

The influence of the co-substrate concentration $\left(\mathrm{H}_{2} \mathrm{O}_{2}\right)$ was studied in the 0.21-2.86 mM range using $A B 10$ as substrate. The decrease of the absorbance at $611 \mathrm{~nm}$ was continuously measured for $3500 \mathrm{~s}$ at $25^{\circ} \mathrm{C}$, using a Jasco V-530 UV/vis Spectrophotometer.

\section{Immobilization by covalent binding on epoxy supports}

$900 \mu \mathrm{l}$ of peroxidase solution $(1.5 \mathrm{mg} / \mathrm{mL})$ in $50 \mathrm{mM}$ phosphate buffer $\mathrm{pH} 6.5$ was added to $100 \mathrm{mg}$ epoxy-activated support. The mixture was incubated for 24 hours at $1000 \mathrm{rpm}$ and $25^{\circ} \mathrm{C}$. The immobilized peroxidase was separated by filtration. At the end of the immobilization, the resin was washed 3 times with $20 \mathrm{mM}$ phosphate buffer, $\mathrm{pH} 6.5$, and stored at $4^{\circ} \mathrm{C}$ until subsequent use.

\section{$\mathrm{pH}$ profile of the immobilized peroxidase}

The effect of $\mathrm{pH}$ on the activity of immobilized HRP $(5 \mathrm{mg} / \mathrm{mL})$ was investigated in the range of $\mathrm{pH} 4.0-12.0$, using a wide $\mathrm{pH}$ buffer solution containing citric acid, boric acid and trisodium phosphate buffer [29]. The $\mathrm{pH}$ profile of native HRP $(20 \mu \mathrm{L}, 1 \mathrm{mg} / \mathrm{mL})$ was determined in the same conditions, as reference. The activity assay was performed as described in previous section.

\section{Degradation of azo dyes by immobilized HRP}

Six different dyes were used to determine the decolorization percentage subsequent to oxidation with immobilized HRP at two $\mathrm{pH}$ values, 3.5 and 6 . The dye solutions were at $10 \mathrm{mg} / \mathrm{mL}$ concentration, and the experiments were carried out in different $\mathrm{pH}$ buffers (1 $\mathrm{mL}$ buffer) at room temperature after $3 \mathrm{~h}, 12 \mathrm{~h}$ and $24 \mathrm{~h}$, respectively. The decrease of the absorbance was monitored by using a Jasco V-530 UV/vis Spectrophotometer. 


\section{Effect of temperature on the activity of immobilized HRP}

The native $(20 \mu \mathrm{L}$ native enzyme $1 \mathrm{mg} / \mathrm{mL}) . /$ immobilized $(5 \mathrm{mg} /$ $\mathrm{mL}$ ) enzyme was incubated for 2 hours in buffer, $\mathrm{pH} 5.0$ in the absence of the substrate at different temperatures, in the range of $25^{\circ} \mathrm{C}$ to $55^{\circ} \mathrm{C}$, followed by cooling on ice for 10 minutes and $A B 10$ substrate was added and the decrease of the absorbance was monitored by using a Jasco V-530 UV/vis Spectrophotometer after $30 \mathrm{~min}$.

\section{Repeated use of the biocatalyst}

The immobilized HRP activity was determined after repeated use of the biocatalyst at $30^{\circ} \mathrm{C}$ for 2 hours buffer, $\mathrm{pH} \mathrm{5}$, with Amido black 10 as substrate. After each cycle, the immobilized enzyme was separated by filtration and washed three times with $50 \mathrm{mM}$ phosphate buffer $\mathrm{pH}$ 6.5. A new reaction cycle was performed by adding the same amount of buffer and substrate. The decolorization percentage achieved with the reused biocatalyst was determined as previously described, and the resulting value was compared to the first cycle (set as 100\%).

SUPPLEMENTARY MATERIALS can be obtained by request from the authors.

\section{REFERENCES}

1. S. Nouren; H.N. Bhatti; Biochem. Eng. J., 2015, 95, 9-19.

2. F. Gholami-Borujeni; A. H. Mahvi; S. Naseri; M. A. Faramarzi; R. Nabizadeh; M.Alimohammadi; Res. J. Chem. Environ., 2011, 15(2), 217-220.

3. J. T. Chacko; K. Subramaniam; Int. J. Environ. Sci., 2011, 1(6), 1250-1256.

4. M. Monier; D.M. Ayad; Y. SAA Wei; Int. J. Biol. Macromol., 2010, 46, 324-330.

5. M. Matto; Q. Husain; Ecotoxicol. Environ. Saf., 2009, 72, 965-971.

6. R. G. Saratale; G. D. Saratale; J. S. Chang; S.P. Gowindvar; J. Taiwan. Inst. Chem. Eng., 2011, 42, 138-157.

7. G.R. Lopes; D.C.G.A. Pinto; A.M.S. Silva; RSC Adv., 2014, 4, 37244-37265.

8. L. Y. Juna; L. S. Yon; N.M. Mubarak; C. H. Bing; S. Pan; M. K. Danquah; E.C. Abdullah; M. Khalid; J. Environ. Chem. Eng., 2019, 7, 1-14.

9. X. Xie; P. Luo; J. Han; T. Chen; Y. Wang; Y. Cai; Q. Liu; Enzyme Microb. Technol., 2019, 122, 26-35

10. B. Yu; H. Cheng; W. Zhuang; C. J. Zhu; J. Wu; H. Niu; D. Liu; Y. Chen; H. Ying; Process Biochem., 2019, 79, 40-48.

11. S. Venkata Mohan; K. Krishna Prasad; N. Chandrasekhara Rao; P.N. Sarma; Chemosphere, 2005, 58, 1097-1100.

12. O. Prodanović; M. Prokopijević; D. Spasojević; Z. Stojanović; K. Radotić; Z.D. Knežević-Jugović; R. Prodanović, Appl. Biochem. Biotechnol., 2012, 168, 1288-1301. 
PAULA BORZA, IOANA CRISTINA BENEA, IOAN BÎTCAN, ANAMARIA TODEA, SIMONA GABRIELA MUNTEAN, FRANCISC PETER

13. J. L. Gómez; A. Bódalo; E. Gómez; J. Bastida; A. M. Hidalgo; M. Gómez; Enzime. Microb. Technol., 2006, 39, 1016-1022.

14. Z. Zhao; M. C. Zhou; R. L. Liu; Catalysts, 2019, 9 (647), 1-15.

15. C. Mateo; O. Abian; R. F. Lafuente; J. M. Guisan; Enzyme Microb. Technol. 2000, 26, 509-515.

16. C. Mateo; V. Grazu; F. Lopez-Gallego; R. Fernandez-Lafuente; Nat. Protoc., 2007, 2(5), 1022-1033.

17. C. Mateo; J. M. Palomo; G. Fernandez-Lorente; J. M Guisan; R. FernandezLafuente, Enzym. Microb. Technol., 2007, 40, 1451-1463.

18. L. Pramparo; F. Stüber; J. Font; A. Fortuny; A. Fabregat; C. Bengoa; J. Hazardous Mat., 2010, 177, 990-1000.

19. H. Sun; X. Jin; N. Long; R. Zhang; Int. J. Biol. Macromol., 2017, 95, 1049-1055.

20. E. Biró; D. Budugan; A. Todea; F. Péter; S. Klébert; T. Feczkó; J. Mol. Catal. B Enzym., 2016, 123, 81-90.

21. B. Sahoo; S.K. Sahu; P. Pramanik; J. Mol. Catal. B: Enzym., 2011, 69, 95-102.

22. A. Cimporescu; A. Todea; V. Badea; C. Paul; F. Peter, Process Biochem., 2016, 51, 2076-2083.

23. M. Bilal; M. N. H. Iqbal; S. Z. H. Shah; H. Hu; W. Wang; X. Zhang; J. Environ. Manage., 2016, 183, 836-842.

24. S. A. Mohameda; A. A. Darwish, R.M.El-Shishtawy, Process Biochem., 2013, 48, 649-655

25. M. Bilal; H. M. N. Iqbal; H. Hu; W. Wang; X. Zhang; Sci. Total Environ., 2017, 575, 1352-1360.

26. M. Monier; D. M. Ayad; Y. Wei; A.A. Sarhan; Int. J. Biol. Macromol., 2010, 46(3), 324-330.

27. T. M. Silva, P. O. Santiago; L. L. A. Purcena, K. F. Fernandes, Mat. Sci. Eng. C-Mater, 2010, 30, 526-530.

28. H. Cai; X. Liu; J. Zou; J. Xiao; B. Yuan; F. Li; Q. Cheng; Chemosphere, 2018, 193, 833-839.

29. W.R. Carmody, J. Chem. Educ., 1961, 38, 559-560. 